\title{
Prevalence of vero toxic Escherichia coli in fecal samples of domestic as well as wild ruminants in Mathura districts and Kanpur zoo
}

\author{
Raghavendra Prasad Mishra ${ }^{1}$, Udit Jain ${ }^{1}$, Basanti Bist ${ }^{1}$, Amit Kumar Verma² and Ashok Kumar ${ }^{3}$
}

1. Department of Veterinary Public Health, College of Veterinary Sciences and Animal Husbandry, Pandit Deen Dayal Upadhayay Pashu Chikitsa Vigyan Vishvidhyalaya Ewam Go-Anusandhan Sansthan, Mathura - 281 001, Uttar Pradesh,

India; 2. Department of Veterinary Epidemiology and Preventive Medicine, College of Veterinary Sciences and Animal

Husbandry, Pandit Deen Dayal Upadhayay Pashu Chikitsa Vigyan Vishvidhyalaya Ewam Go-Anusandhan Sansthan,

Mathura - 281 001, Uttar Pradesh, India; 3. Division of Veterinary Public Health, Indian Veterinary Research Institute, Izatnagar, Bareilly, Uttar Pradesh, India.

Corresponding author: Raghavendra Prasad Mishra, e-mail: rmishra523@rediffmail.com,

UJ: druditjain@hotmail.com, BB: vasanti.bist@gmail.com, AKV: drakverma79@gmail.com, AK: ashokakt@rediffmail.com Received: 28-08-2015, Revised: 08-12-2015, Accepted: 14-12-2015, Published online: 21-01-2016

doi: 10.14202/vetworld.2016.71-74 How to cite this article: Mishra RP, Jain U, Bist B, Verma AK, Kumar A (2016) Prevalence of vero toxic Escherichia coli in fecal samples of domestic as well as wild ruminants in Mathura districts and Kanpur zoo, Veterinary World 9(1): 71-74.

\begin{abstract}
Aim: The present study was planned to reveal the prevalence of verocytotoxigenic Escherichia coli (VTEC) in fecal samples of domestic and wild ruminants in Mathura district and Kanpur zoo.

Materials and Methods: A total of 240 fecal samples comprising 60 each of cattle, buffalo, sheep and deer from Mathura districts and Kanpur zoo were screened for the presence of E. coli and VTEC genes positive by polymerase chain reaction (PCR).

Result: Out of 240 fecal samples, 212 E. coli strains were obtained. All the E. coli isolates were screened by PCR to detect virulence genes $s t x_{1}$, stx , eaeA and $h l y A$. Of these, 25 isolates were identified as VTEC. The prevalence of VTEC in cattle, buffalo, sheep and deer was found 13.4\% (8/60), 13.4\% (8/60), 6.67\% (4/60) and 8.33\% (5/60), respectively.

Conclusion: $s t x_{1}$, stx, eaeA and $h l y A$ genes were prevalent in VTEC isolates from feces of cattle, buffalo, sheep and deer population of Mathura districts and Kanpur zoo. The presence of VTEC isolates in this region may pose a threat to public health.
\end{abstract}

Keywords: domestic and wild ruminants, feces, prevalence, polymerase chain reaction, verotoxic Escherichia coli.

\section{Introduction}

Diarrhea is one of the most common multifactorial diseases of man and animals mainly caused by Escherichia coli [1]. E. coli is the most common observed gastrointestinal flora of animals and environmental contaminant considered as important foodborne pathogen causing serious complications in man and animals [2-5].

Verocytotoxigenic $E$. coli (VTEC) was the first identified as a distinct group of $E$. coli named as VTEC, which had the ability to produce toxins with profound and irreversible effect on vero cells. VTEC is also termed as shiga-like toxin producing $E$. coli (SLTEC) or shiga toxin producing E. coli or STEC. Acronym STEC is derived from the fact that the toxins are shiga like that is similar to those produced by Shigella dysenteriae Type 1 [6].

The enterohemorragic E. coli belong to the VTEC. VTEC always do not induce clinical signs and

Copyright: Mishra, et al. Open Access. This article is distributed under the terms of the Creative Commons Attribution 4.0 International License (http://creativecommons.org/licenses/by/4.0/), which permits unrestricted use, distribution, and reproduction in any medium, provided you give appropriate credit to the original author(s) and the source, provide a link to the Creative Commons license, and indicate if changes were made. The Creative Commons Public Domain Dedication waiver (http://creativecommons.org/ publicdomain/zero/1.0/) applies to the data made available in this article, unless otherwise stated. are not enterohemorrhagic until addition virulence factor are present like enterohemolysin and adherence factors (intimin). The adherence factor(s) enables the organism to attach to and colonize intestinal mucosal cells [7]. Among VTEC, serotype O157:H7 has been closely associated with the sporadic and clinical outbreaks of hemorrhagic colitis (HC), hemolytic uremic syndrome (HUS) and thrombotic thrombocytopenic purpura (TTP) in human beings [8-10]. Healthy domestic ruminants are recognised as the main natural reservoir of STEC and large game animal may be healthy carriers of STEC $[11,12]$.

Keeping in view the importance of this organism, the present study was planned to reveal the prevalence of VTEC in fecal samples of domestic and wild ruminants in Mathura district and Kanpur zoo.

\section{Materials and Methods}

\section{Ethical approval}

This work does not require ethical approval because we have collected fecal samples of animals after defecation.

\section{Sampling and isolation of $E$. coli}

A total of 240 samples of feces (180 domestic ruminants 60 wild ruminants) were collected from Mathura district and Kanpur zoo. The samples were collected aseptically in UV sterile polythene bags 
(Fisher Scientific, UK) and immediately transported to the laboratory under chilled conditions for microbiological analysis. For primary isolation of E. coli (VTEC), $10 \mathrm{~g}$ of fecal sample were enriched in $90 \mathrm{ml}$ modified trypticase soya broth (mTSB) (Himedia, Mumbai) containing acriflavine $(10 \mathrm{mg} / \mathrm{ml})$ to reduce the growth of Gram-positive organism. The method used for collection of materials, and isolation and identification techniques were performed as suggested by the World organization for Animal Health [13]. These samples were incubated at $37^{\circ} \mathrm{C}$ for $6 \mathrm{~h}$. MacConkey's agar was used as differential media while eosin methylene blue agar (Hi-Media, Mumbai) was used as selective media. Suspected E. coli strains were subjected to morphological, cultural and biochemical characterization as per standard methods [14]. A statistical analysis was done as per the standard method [15].

\section{Molecular characterization}

Multiplex polymerase chain reaction (pcr) was used for detection of virulent genes $\left(s t x_{1}, s t x_{2}\right.$, eaeA, and $h l y A$ ) of VTEC. All the E. coli isolates were subjected to genomic DNA isolation. The bacterial growth in mTSB broth (HiMedia, Mumbai) was centrifuged at $3000 \mathrm{rpm}$ for $15 \mathrm{~min}$ to make the pellet of bacterial cells. These cells were washed twice with phosphate-buffered saline ( $\mathrm{pH}$ 7.4) to remove any impurity of broth media. Bacterial DNA was extracted by using DNA extraction kit (Genei, Bangalore) as per the manufacturer's protocol. For the PCR reaction, PCR Master Mix solution (Genei, Bangalore) was used. DNA amplification targeted to virulent genes $\left(s t x_{1}, s t x_{2}\right.$, eaeA and $\left.h l y A\right)$ of VTEC was performed using primers on $3 \mu 1$ of DNA sample in $25 \mu 1$ reaction mixture [16]. After an initial denaturation step at $95^{\circ} \mathrm{C}$ for $4 \mathrm{~min}, 30$ amplification cycles were performed, each consisting of $2 \mathrm{~min}$ at $94^{\circ} \mathrm{C}, 2 \mathrm{~min}$ at $65^{\circ} \mathrm{C}$, and $1.5 \mathrm{~min}$ at $72^{\circ} \mathrm{C}$ and followed by a final extension step at $72^{\circ} \mathrm{C}$ for $2.5 \mathrm{~min}$. After the amplification, amplicons were separated in $1.5 \%$ gel in tris acetate EDTA (TAE) buffer at 60 volt for $80 \mathrm{~min}$, stained with $0.5 \%$ ethidium bromide solution and visualized under ultraviolet light.

\section{Results and Discussion}

Out of 240 fecal samples, a total of 212 E. coli strains were obtained (Table-1). All the strains of $E$. coli were screened to detect the presence of VTEC genes using PCR. An overall prevalence of VTEC in ruminants (both wild and domestic) was found to be $10.42 \%(25 / 240)$. The highest prevalence of VTEC was reported in cattle and buffalo $13.4 \%(8 / 60)$ in each followed by sheep $6.67 \%(4 / 60)$ and deer $08.33 \%$ $(5 / 60)$. In cattle, 2 VTEC were found to be positive for $s t x_{1}$ gene $(180 \mathrm{bp})$ and 6 VTEC for $s t x_{1}$ and $\mathrm{s} t x_{2}(180 \mathrm{bp}$ and $255 \mathrm{bp}$ ). In buffalo, 3 VTEC were found positive for $s t x_{1}$ gene and 5 was positive for $s t x_{1}$ and $s t x_{2}$. In sheep, out of 4 VTEC, only one VTEC was having $s t x_{1}$ gene and 3 VTEC isolates having $s t x_{1}$ and $s t x_{2}$ both. In wild ruminants (deer), out of 5 VTEC, only one was found to be positive for $s t x_{1}$ gene, one isolates was found to be positive for stx, with hlyA (534 bp), one stx, with eaeA (384 bp) and two VTEC have stx, eaeA and $h l y A$ genes. Two $E$. coli strains were found having eaeA with $h l y A$ genes, i.e., lacking stx gene and they may be enteropathogenic.

In the previous study, the prevalence of VTEC in sheep, cattle and buffalo were reported as $4.81 \%$ [17], $7.4 \%$ [18] and $8.9 \%$ [19], respectively. However, the prevalence of VTEC in higher level was reported by previous workers as the prevalence of VTEC was $16.66 \%$ [20], $18 \%$ [21] and $18.47 \%$ [22]. In contrast, investigations have shown a higher detection rate of $46 \%$ [23] in fecal samples of cattle and buffalo. Lower isolation rate, i.e. 9\% [24]. Isolation rate as low as $1.0 \%$ has also been reported [25]. In deer previously reported, the prevalence of VTEC 9.3\% [26], 16.2\% [27] and16.5\% [28], which likely similar as present finding. These hazardous strains of $E$. coli have been given immense attention due to their involvement in serious illnesses like HC (bloody diarrhea, HC), HUS and TTP in human [29-31]. The low infective dose, unusual acid tolerance and close association with ruminants have made VTEC a serious global zoonotic problem of great public health significance. VTEC can be present in the intestinal tract of a wide range of domestic and wild animals and ruminants (sheep, goats, cattle, buffalo and deer) [32-36], especially cattle and buffalo are considered as a major reservoir for VTEC [37,38].

\section{Conclusion}

The presence of VTEC in feces causes fecal contamination of water, and also contaminates other food sources, thus depicts a dangerous picture regarding human and animal health safety because water is essential for the survival of every living being. Constant monitoring and surveillances program to keep a record of the prevalence from time to time is needed, and proper hygienic measure may reduce the chance of infection.

\section{Authors' Contributions}

$\mathrm{UJ}, \mathrm{BB}$ and $\mathrm{AKV}$ designed and planned this research work. RPM collected the samples and executed the isolation and biochemical work. UJ monitored the isolation, biochemical characterization. RPM and UJ was involved in the molecular characterization experiment. Manuscript was drafted and revised by AK, BB \& RPM under the guidance of UJ. All authors read and approved the final manuscript.

\section{Acknowledgements}

The authors are highly thankful to Indian Council of Agricultural Research, New Delhi and Dean, College of Veterinary Science and Animal Husbandry, Uttar Pradesh Pandit Deen Dayal Upadhayay Pashu Chikitsa Vigyan Vishvidhyalaya 
Table-1: Details of sample collection and prevalence of $E$. coli and VTEC in fecal sample.

\begin{tabular}{|c|c|c|c|c|c|}
\hline Sources* & Place of collection & $\begin{array}{c}\text { Number of sample } \\
\text { collected }\end{array}$ & $\begin{array}{l}\text { Percentage of } \\
\text { E. coli }\end{array}$ & $\begin{array}{l}\text { No. of VTEC } \\
\text { isolates }\end{array}$ & $\begin{array}{l}\text { Percentage } \\
\text { of VTEC }\end{array}$ \\
\hline \multirow[t]{3}{*}{ Cattle } & DDD farm DUVASU, Mathura & 35 & $85.7(30 / 35)$ & 7 & 20 \\
\hline & Gaushalas of Vrindavan & 15 & $93.4(14 / 15)$ & 1 & 6.67 \\
\hline & TVCC Kothari & 10 & $90(9 / 10)$ & 0 & 0 \\
\hline \multirow[t]{2}{*}{ Buffalo } & DDD farm DUVASU, Mathura & 40 & $95.6(38 / 40)$ & 8 & 20 \\
\hline & TVCC Kothari & 20 & $90(18 / 20)$ & 0 & 0 \\
\hline \multirow[t]{3}{*}{ Sheep } & Sheep farm DUVASU, Mathura & 30 & $86.7(26 / 30)$ & 2 & 6.67 \\
\hline & Sheep farm, farah & 20 & $80(16 / 20)$ & 1 & 5 \\
\hline & Aurangabad & 10 & $70(7 / 10)$ & 1 & 10 \\
\hline \multirow[t]{2}{*}{ Deer } & Kanpur Zoo & 30 & $86.7(26 / 30)$ & 2 & 6.66 \\
\hline & Ramanreti & 30 & $93.4(28 / 30)$ & 3 & 10 \\
\hline Total & & 240 & $88.5(212 / 240)$ & 25 & $10.41(25 / 240)$ \\
\hline
\end{tabular}

$\mathrm{p}<0.05, \mathrm{VTEC}=$ Verocytotoxigenic Escherichia coli, E. coli=Escherichia coli

Ewam Go-Anusandhan Sansthan (DUVASU), Mathura, Uttar Pradesh, India for providing necessary funds and facilities to carry out the investigations.

\section{Competing Interests} interests.

The authors declare that they have no competing

\section{References}

1. Kumar, A., Verma, A.K., Sharma, A.K. and Rahal, A. (2013) Presence of extended spectrum Beta-lactamases producing alpha hemolytic Escherichia coli in yellow-wattled Lapwing (Vanellus malabaricus). Asian J. Anim. Sci., 7(2): 64-69.

2. Mailk, S., Kumar, A., Verma, A.K., Gupta, M.K., Sharma, S.D., Sharma, A.K. and Rahal, A. (2013) Incidence and drug resistance pattern of collibacillosis in cattle and buffalo calves in Western Uttar Pradesh in India. J. Anim. Health Prod., 1(1): 15-19.

3. Dhama, K., Rajagunalan, S., Chakraborty, S., Verma, A.K., Kumar, A., Tiwari, R. and Kapoor, S. (2013) Food-borne pathogens of animal origin-diagnosis, prevention and control and their zoonotic significance - A review. Pak. J. Biol. Sci., 16(20): 1076-1085.

4. Kumar, A., Verma, A.K., Malik, S., Gupta, M.K., Sharma, A. and Rahal, A. (2014) Occurrence of extended spectrum beta-lactamases producing alpha hemolytic Escherichia coli in neonatal diarrhea. Pak. J. Biol. Sci., 17(1): 109-113.

5. Anita, Kumar, A., Verma, A.K., Gupta, M.K. and Rahal, A. (2014) Multi drug resistant pathogenic Escherichia coli in water sources and Yamuna River in and around Mathura, India. Pak. J. Biol. Sci., 17(4): 540-544.

6. O'Brien, A.D. and Holmes, R.K. (1987) Shiga and Shigalike toxins. Microbiol. Rev., 51: 206-220.

7. Hiruta, N., Murase, T. and Okamura, N. (2001) An outbreak of diarrhoea due to multiple antimicrobial resistant Shiga toxin producine E.coli $\mathrm{O} 26: \mathrm{H} 7$ ina nursery. Epidemiol. Infect., 127: 221-227.

8. Croxen, M.A. and Finlay, B.B. (2010) Molecular mechanisms of Escherichia coli pathogenicity Nat. Rev. Microbiol., 8: 26-38.

9. Gyles, C.M. and Fairbrother, J.M. (2010) Escherichia coli In: Gyles, C.L., Prescott, J.F., Thoen, C.O., editors. Pathogenesis of Bacterial Infections in Animals. Blackwell Publishing, Ames, p267-308.

10. Sanchez, S., Sanchez, D.S., Martinez, R., Llorente, M.T., Herrera-Leon, S. and Vidal, D. (2013) The new allelic variantof the subtilase cytotoxin ( $\left(\mathrm{ub} \mathrm{AB}_{2}\right.$ ) is common among Shiga toxin producing Escherichia coli strains from large animals and their meat and meat products. Vet. Microbiol., 166: 645-649.

11. Diaz, S., Vidal, D., Herrera-Leon, S. and Sanchez, S. (2011) Sorbitol-fermenting, b-glucuronidase-positive, Shiga toxin negative Escherichia coli $\mathrm{O} 157: \mathrm{H} 7$ in free-ranging red deer in South-Central Spain. Foodborne Pathog. Dis., 8: 1313-1315.

12. Sanchez, S., Martnez, R., Garca, A., Vidal, D., Blanco, J., Blanco, M., Blanco, J.E., Mora, A., Herrera-Leon, S., Echeita, A., Alonso, J.M. and Rey, J. (2010) Detection and characterization of $\mathrm{O} 157: \mathrm{H} 7$ and non-O157 Shiga toxin producing Escherichia coli in wild boars. Vet. Microbiol., 143: 420-423.

13. OIE. (2004) Verocytotoxigenic Escherichia coli. In: Word Organization for Animal Health, Pairs manual of Diagnostic Tests and Vaccines for Terrestrial Animals. $5^{\text {th }}$ ed. OIE, Paris.

14. Ewing, W.H. (1986) The genus Escherichia. In: Edwards, P.R., Ewing, W.H., editors. Edwards and Ewing's identification of Entero Bacteriaceae. $4^{\text {th }}$ ed. Elsevier Science Publishing Co., Inc., NewYork. p93-122.

15. Snecedor, G.W. and Cochran, W.G. (1994) In: Statistical Methods. $8^{\text {th }}$ ed. IOWA State University Press, Ames, IOWA.

16. Paton, A.W. and Paton, J.C. (1998) Detection and characterization of shiga toxigenic Escherichia coli by using multiplex PCR Assays for $s t x_{1}$, stx 2 , eaeA, enterohemorrhagic $E$. coli hly A, rfb O111, and $r f b$ O157 J. C. Microbial, February. p598-602.

17. Chattopadhyay, U.K., Gupta, S. and Dutta, S. (2003) Search for Shiga toxin producing Escherichia coli (STEC) including O157:H7 strains in and around Kolkata. Indian J. Med. Microbiol., 21: 17-20.

18. Cobbold, R.N., Rice, D.H., Szymanski, M., Call, D.R. and Hancock, D.D. (2004) Comparison of Shiga - Toxigenic Escherichia coli prevalences among dairy, feedlot and cow calf herds in Washington State. Appl. Environ. Microbiol., 70: 4375-4378

19. Eriksson, E., Aspon, A., Gunnarsson, A. and Vagsholm, I. (2005) Prevalence of verotoxin producing Escherichia coli (VTEC) O157 in Swedish dairy herds. Epidemiol. Infect., 133: 349-358.

20. Parul, Bist, B., Sharma, B. and Manjula. (2014) Prevalence of verotoxin producing Escherichia coli non O157 in diarrhoeic and healthy calves. One Health: Harnesting biotechnology for addressing veterinary and biomedical concerns on food safety, zoonoses and environment sustainability. $12^{\text {th }}$ Annual Conference of IAVPHS, Guwahati, India. p245-246.

21. Rogerie, F., Marecat, A., Gambade, S., Dupond, F., Beaubois, P. and Lange, M. (2001) Characterization of Shiga toxin producing E. coli and O157 serotype isolated in France from healthy domestic cattle. Int. J. Food Microbiol., 63: 217-223.

22. Rabin, B. (1999) Prevalence of verotoxic Escherichia coli in man animals, food and pulic health significance. M. V. Sc Thesis, Deemed University, IVRI, Izatnagar. 
23. Kobayashi, H., Shimada, J., Nakazawa, M., Morozumi, T., Pohjanvirta, T., Pelkonen, S. and Yamamoto, K. (2001) Prevalence and characteristics of Shiga toxin-producing Escherichia coli from healthy cattle in Japan. Appl. Environ. Microbiol., 67: 484-489.

24. Blanco, M., Blanco, J., Blanco, J.E. and Ramos, J. (1993) Enterotoxigenic, verotoxigenic and necrotoxigenic Escherichia coli isolated from cattle in Spain. Am. J. Vet. Res., 54: 1446-1451.

25. Khurana, P. and Kumar, A. (2005) Occurance of verotoxic $E$. coli in faeces and milk of cattle. Harayana Vet., 44: 83-85.

26. Bardiau, M., Gregoire, F., Muylaert, A., Nahayo, A., Duprez, J.N., Mainil, J. and Linden, A. (2010) Enteropathogenic (EPEC), enterohaemorragic (EHEC) and verotoxigenic (VTEC) Escherichia coli in wild cervids. J. Appl. Microbiol., 109(6): 2214-2222.

27. Hiroshi, A., Sou-ichi, M., Toshikazu, S., Teizo, T., Hisao, K., Tetsuya, I. and Kouichi, T. (2013) Detection and genetical characterization of Shiga toxin-producing Escherichia coli from wild deer. Microbiol. Immunol., 42(12): 815-822.

28. Sanchez, S., Martínez, R., Rey, J., García, A., Blanco, J., Blanco, M., Blanco, J.E., Mora, A., Herrera-León, S., Echeita, A. and Alonso, J.M. (2010) Pheno-genotypic characterisation of Escherichia coli O157:H7 isolates from domestic and wild ruminants. Vet. Microbiol., 142(3-4): 445-9.

29. Scotland, S.M., Willshaw, G.A., Smith, H.R. and Rowe, B. (1987) Properties of strains of Escherichia coli belonging to serogroup 0157 with special reference to production of Verocytotoxins VT1 and VT2. Epidemiol. Infect., 99: 613-624

30. Karmali, M.A. (1989) Infection by verocytotoxin-producing Escherichia coli. Clin. Microbiol. Rev., 2: 15-38.
31. Wani, S.A., Bhat, M.A., Samanta, I., Ishaq, S.M., Ashraff, M.A. and Buchh, A.S. (2004) Epidemiology of diarrhoea caused by rota virus and Escherichia coli in lambs in Kashmir Valley, India. Small Rumin. Res., 52: $145-153$

32. Beutin, L., Geier, D., Zimmerman, S. and Karch, H. (1995) Virulence markers of Shiga-like toxin-producing E. coli strains from healthy domestic animals of different species. J. Clin. Microbiol., 33: 631-635.

33. Chapman, P.A. and Siddons, C.A. (1997) A comparison of immunomagnetic separation and direct culture for the isolation of verocytotoxin-producing Escherichia coli $\mathrm{O} 157$ from cases of bloody diarrhoea, non-bloody diarrhoea and asymptomatic contacts. J. Med. Microbiol., 44: 267-271.

34. Johnson, R.P., Clarke, R.C. and Gyles, C.L. (1996) Growing concerns and recent outbreaks involving non-O157:H7 serotypes of verotoxigenic Escherichia coli. J. Food Protect., 59: 1112-1122.

35. Schouten, J.M., van de Giessen, A.W., Frankena, K., De Jong, M.C.M. and Graat, E.A.M. (2005) Escherichia coli $\mathrm{O} 157$ prevalence in dutch poultry, pig finishing and veal herds and risk factors in dutch veal herds. Prev. Vet. Med., 70: 1-15.

36. Oporto, B., Esteban, J.I., Aduriz, G., Juste, R.A. and Hurtado, A. (2008) Escherichia coli O157:H7 and nonO157 Shiga toxin-producing E. coli in healthy cattle, sheep and swine herds in Northern Spain. Zoonoses Public Health., 55(2): 73-81.

37. Mainil, J. (1999) Shiga/verocytotoxins and Shiga/verotoxigenic Escherichia coli in animals. Vet. Res., 30: 235-257.

38. Krause, G., Zimmermann, S. and Beutin, L. (2005) Investigation of domestic animals and pets as a reservoir for intimin - (eae) gene positive Escherichia coli types. Vet. Microbiol., 106: 87-95.

$* * * * * * * *$ 